\title{
PENCEGAHAN PERNIKAHAN USIA DINI MELALUI PENYULUHAN KESEHATAN DI KELURAHAN BOLIHUANGGA
}

\author{
Wahyuni Hafid ${ }^{1,}$ Zul Adhayani Arda ${ }^{2,}$ Sunarti Hanapi ${ }^{3}$
}

\author{
Universitas Gorontalo, Indonesia ${ }^{1}$ \\ Email:wahyunihafid292@gmail.com \\ Universitas Gorontalo, Indonesia ${ }^{2}$ \\ Email: adhayani r@yahoo.co.id \\ Universitas Gorontalo, Indonesia ${ }^{3}$ \\ Email: sunarti82hanapi@gmail.com
}

\begin{abstract}
Abstrak
Data dari beberapa kantor KUA di Kabupaten Gorontalo menyatakan Kecamatan Limboto merupakan wilayah yang memiliki angka pernikahan usia dini (16-18 tahun) tertinggi selama tiga tahun berturut-turut (2018-2020) sebanyak 168 pernikahan. Kelurahan Bolihuangga merupakan salah satu kelurahan yang terdapat di Kecamatan Limboto yang memiliki jumlah remaja usia 16-18 tahun terbanyak yaitu 278 orang sehingga mendukung dalam penerapan kegiatan pengabdian ini sebab yang menjadi kelompok sasaran penyuluhan adalah remaja yang berusia 16-18 tahun. Berdasarkan hal tersebut kegiatan penyuluhan kesehatan khususnya terkait pendewasaan usia pernikahan dan dampak negatif pernikahan usia dini merupakan salah satu aspek yang sangat diperlukan untuk membantu meningkatkan pengetahuan, sikap, dan kesadaran diri remaja terkait fenomena pernikahan usia dini. Kegiatan pengabdian ini bertujuan untuk meningkatkan pengetahuan, sikap dan kesadaran diri remaja sebagai upaya pencegahan pernikahan usia dini yang diterapkan pada 32 remaja dengan metode penyuluhan. Pengabdian ini menghasilkan penyuluhan dengan tema "Aku Cinta Masa Depanku", penayangan film pendek terkait dampak pernikahan usia dini disertai diskusi, pembagian poster/leaflet sebagai penunjang peningkatan pengetahuan, sikap dan kesadaran diri tentang pernikahan usia dini, dan pembentukan komunitas Fresh Milk (Forum Remaja Sehat Milenial Kreatif) sehingga bisa menjadi percontohan dan pemberi edukasi teman sebaya. Rencana target luaran (output) kegiatan ini yaitu peningkatan pengetahuan, sikap, dan kesadaran diri remaja terkait dampak pernikahan dini sebagai upaya pencegahan pernikahan usia dini.
\end{abstract}

Kata Kunci: Penyuluhan, Pengetahuan, Sikap, Remaja, Pernikahan Usia Dini.

\section{Abstract}

Data from several KUA offices in Gorontalo District states that Limboto District is an area that has the highest early marriage rate (16-18 years) for three consecutive years (2018-2020) with 168 marriages. Bolihungga Village is one of the villages in Limboto District which has the highest number of adolescents aged 16-18 years, namely 278 so that it supports the implementation of this service activity because the target group for counseling is adolescents aged 16-18 years. Based on this, health education activities, especially related to the maturity of marriage, and the negative impact of early marriage is one aspect that is very necessary to help increase the knowledge, attitudes and self-awareness of adolescents related to the phenomenon of early childhood marriage. This service activity aims to increase the knowledge, attitudes and self-awareness of adolescents as an effort to prevent early marriage which is applied to 32 adolescents with counseling methods. This service resulted in counseling with the theme "I Love My Future", showing short films related to the impact of early marriage with discussion, making posters/leaflets to support increasing knowledge, attitudes and self-awareness about early marriage, and forming the Fresh Milk community (Teenager Forum. Healthy, Millennials Creative) so that they can become role models and educators for their peers. The planned output 
of this activity is to increase the knowledge, attitudes, and self-awareness of adolescents regarding the impact of early marriage as an effort to prevent early marriage.

Keywords: Counseling, Knowledge, Attitudes, Adolescents, Early Marriage.

\section{PENDAHULUAN}

Tren perkawinan anak perempuan di Indonesia, baik yang melangsungkan perkawinan pertama sebelum usia 18 tahun maupun 15 tahun, menunjukkan penurunan pada periode tahun 2008 sampai 2018, namun penurunannya masih dikategorikan lambat. Pada tahun 2008, prevalensi perkawinan anak sebesar 14,67 \%, namun pada satu dekade kemudian (tahun 2018) hanya menurun 3,4 \% sehingga prevalensi perkawinan menjadi 11,21\%. Sekitar 1 dari 9 perempuan berusia 20-24 tahun melangsungkan perkawinan pertama sebelum usia 18 tahun (Badan Pusat Statistik, 2020).

Fenomena pernikahan dini di Kecamatan Limboto semakin meningkat selama tiga tahun terakhir, hal tersebut dapat dibuktikan berdasarkan data dari beberapa Kantor Urusan Agama (KUA) di Kabupaten Gorontalo yang menunjukkan bahwa jumlah remaja yang menikah dini pada tahun 2018 sampai 2020 terdapat 544 orang. Kecataman Limboto merupakan kecamatan dengan angka pernikahan tertinggi selama tiga tahun terakhir yaitu pada tahun 2018 tercatat 78 orang yang terdiri dari laki-laki 7 orang dan perempuan 71 orang, tahun 2019 tercatat 51 orang terdiri dari laki-laki 7 orang dan perempuan 44 orang, dan di tahun 2020 tercatat 39 orang terdiri dari 5 orang laki laki dan perempuan 34 orang (Kantor Urusan Agama Limboto, 2020).

Fenomena pernikahan dini, pihak perempuan seringkali menjadi korbannya. Remaja perempuan yang hamil sebelum menikah, akan mendapat tekanan dari masyarakat jika tidak menikah dan menjadi bahan perbincangan. Padahal, dampak dari pernikahan yang terlalu dini bagi kesehatan remaja perempuan dapat menyebabkan peningkatan kematian ibu karena secara fisik belum siap untuk melahirkan. Dampak lainnya adalah kehilangan hak untuk mendapatkan pendidikan, hak untuk mendapatkan perlindungan dari orang tua, dan kondisi ketidaksiapan mental untuk berbagi peran yang mungkin tidak dapat dilakukan secara optimal yang dapat menyebabkan tekanan secara psikologis (Limbong, Deliviana and Indonesia, 2020).

Mengenai dampak negatif pernikahan dini tidak hanya berimbas pada pasangan yang bersangkutan, akan tetapi juga pada lingkungan yang lebih luas lagi. Berdasarkan analisa data perkawinan usia anak di Indonesia hasil kerja sama BPS dan United Nations Children's Fund (UNICEF) (2014), ada berbagai dampak negatif yang dapat terjadi pada sebuah pernikahan yang dilakukan pada usia anak. Dampak bagi anak perempuan antara lain, anak perempuan akan mengalami sejumlah hal dari pernikahan di usia dini. Dampak tersebut diantaranya, tercurinya hak seorang anak. Hak-hak itu antara lain hak pendidikan, hak untuk hidup bebas dari kekerasan dan pelecehan, hak kesehatan, hak dilindungi dari eksploitasi, dan hak tidak dipisahkan dari orangtua. Berkaitan dengan hilangnya hak kesehatan, seorang anak yang menikah di usia dini 
memiliki risiko kematian saat melahirkan yang lebih tinggi dibandingkan dengan wanita yang sudah cukup umur. Selain itu, seorang anak perempuan yang menikah dini akan mengalami sejumlah persoalan psikologis seperti cemas, depresi, bahkan keinginan untuk bunuh diri. Di usia yang masih muda, anak-anak ini belum memiliki status dan kekuasaan di dalam masyarakat. Masih terkungkung untuk mengontrol diri sendiri. Serta pengetahuan seksualitas yang masih rendah meningkatkan risiko terkena penyakit infeksi menular seperti HIV (Suciati, 2019). Beberapa risiko juga mengancam anak-anak yang nantinya lahir dari hubungan kedua orangtua yang menikah di bawah umur. Belum matangnya usia sang ibu, mendatangkan konsekuensi tertentu pada si calon anak. Misalnya, angka risiko kematian bayi lebih besar, bayi lahir dalam keadaan prematur, kurang gizi, dan anak berisiko terkena hambatan pertumbuhan atau stunting. Sementara itu dampak pernikahan dini juga akan terjadi di masyarakat, di antaranya langgengnya garis kemiskinan (https://lifestyle.kompas.com/read/2018/09/05/095311620/ini-akibat-yang-terjadi-daripernikahan-dini).

Sebuah penelitian tentang pernikahan dini di Aceh Tengah juga menunjukkan bahwa perkawinan di bawah umur di kabupaten ini mempunyai hubungan dan pengaruh yang signifikan terhadap tingkat perceraian. Hal tersebut dapat diidentifikasi dari hasil data yang diperoleh malalui Mahkamah Syar'iyah Kabupaten Aceh Tengah, Kantor KUA Kecamatan Lut Tawar dan Kantor KUA Kecamatan Bintang, dan juga dapat dilihat dari hasil wawancara dengan pegawai di lingkungan Mahkamah. Syar'iyah kabupaten Aceh Tengah, KUA Kecamatan Lut Tawar dan KUA Kecamatan Bintang. Berdasarkan data diperoleh $38,8 \%$ kasus perceraian dari total 108 angka pasangan yang menikah di bawah umur dalam kurun waktu tiga tahun dengan rincian sebagai berikut 12 kasus $(37,5 \%)$ perceraian pasangan di bawah umur pada tahun 2014 dari total 32 pasangan yang menikah, pada tahun 2015 sebanyak 16 kasus $(42,10 \%)$ dari 38 pasangan menikah dan tahun 2016 sebanyak 14 kasus (36,84\%) dari 38 pasangan menikah. Persentase ini menunjukkan bahwa pernikahan di bawah umur di Kabupaten Aceh Tengah sangat rentan terhadap perceraian (Fitra, 2017).

Kegiatan pengabdian ini bertujuan untuk meningkatkan pengetahuan, sikap dan kesadaran diri remaja sebagai salah satu upaya pencegahan dan menekan angka kejadian pernikahan usia dini khususnya di Kecamatan Limboto, Kabupaten Gorontalo, Provinsi Gorontalo.

\section{METODE}

Upaya untuk melaksanakan pembangunan yang berpusat pada rakyat dilakukan melalui pemberdayaan dengan kegiatan penyuluhan. Penyuluhan pada prinsipnya merupakan upaya untuk mengubah keberadaan masyarakat menjadi lebih mandiri, produktif dan sejahtera. Pemilihan lokasi pengabdian ini dilakukan secara sengaja (purposive) dengan pertimbangan bahwa Kelurahan Bolihuangga memiliki remaja yang berusia 16-18 tahun terbanyak yaitu 278 orang sehingga mendukung dalam penerapan kegiatan pengabdian ini sebab kelompok sasaran lebih mudah untuk ditemui dan 
dikumpulkan. Metode yang digunakan pada kegiatan pengabdian ini berupa penyuluhan (ceramah), diskusi, pemutaran film pendek terkait dampak pernikahan usia dini, pembagian poster/leaflet sebagai penunjang peningkatan pengetahuan, sikap dan kesadaran diri tentang dampak pernikahan usia dini, dan pembentukan komunitas Fresh Milk (Forum Remaja Sehat Milenial Kreatif) sehingga bisa menjadi percontohan dan pemberi edukasi teman sebaya. Kegiatan ini dihadiri oleh 32 remaja putra dan putri dimana pelaksanaannya selama 5 hari dari tahapan perencanaan sampai pelaksanaan. Rincian tahapan pengabdian sebagai berikut:

1. Proses perencanaan meliputi identifikasi kebutuhan, identifikasi potensi dan kelemahan yang ada, menentukan jalan keluar dan kegiatan yang akan dilakukan, dan membuat pengorganisasian kegiatan. Perencanaan disusun oleh tim pengabdian, pemerintah desa dan karang taruna Kelurahan Bolihuangga.

2. Koordinasi dilakukan antara dosen, mahasiswa, pemerintah desa dan karang taruna untuk pelaksanaan kegiatan ini. Setelah disepakati dan dikoordinasikan rancangan kegiatan yang akan diajukan maka diperoleh kesepakatan hari untuk pelaksanaan rangkaian program penyuluhan.

3. Kegiatan Penyuluhan dengan judul "Pencegahan Pernikahan Usia Dini Melalui Penyuluhan Kesehatan di Kelurahan Bolihuangga" dilaksanakan pada hari Rabu tanggal 31 Maret 2021. Waktu pelaksanaan mulai dari jam o8.oo pagi sampai selesai. Masyarakat yang terlibat antara lain 32 remaja putra dan putri berusia 16-18 tahun, pemerintah desa, dan karang taruna Kelurahan Bolihuangga.

4. Melakukan Penyuluhan Dengan Tema "Aku Cinta Masa Depanku". Pelaksanaan penyuluhan ini untuk memberikan pemahaman kepada remaja terkait pendewasaan usia pernikahan dan dampak negatif yang ditimbulkan oleh pernikahan usia dini yang dapat dijadikan sebagai salah satu upaya pencegahan dan penekanan angka kejadian pernikahan usia dini. Dirangkaikan dengan pembagian poster/leaflet sebagai penunjang peningkatan pengetahuan, sikap dan kesadaran diri tentang dampak pernikahan usia dini

5. Penayangan film pendek tentang akibat pernikahan dini dan diskusi. Penayangan film merupakan media literasi secara visual dalam memahami seluk beluk dan dampak pernikahan dini. Setelah itu dilakukan diskusi dan simulasi tentang isi film. Dengan demikian kesadaran diri remaja untuk menjauhi atau tidak melakukan pernikahan usia dini meningkat.

6. Mahasiswa dan peserta membentuk komunitas Fresh Milk yang merupakan bentuk pendampingan untuk memantau keberlanjutan dari program penyuluhan yang dilaksanakan. Adapun yang akan menjadi anggota komunitas adalah remaja usia sekolah (16-18 tahun) dan mahasiswa. Pada komunitas ini akan dilakukan pendampingan serta pemberdayaan dan dilengkapi dengan grup komunikasi melalui social media yaitu WhatsApp untuk membantu kelancaran komunikasi antara satu sama lain. 


\section{HASIL DAN PEMBAHASAN}

Bentuk partisipasi mitra dalam pelaksanaan kegiatan ini cukup aktif dan menyambut baik program penyuluhan dengan tema "Aku Cinta Masa Depanku". Bentuk partisipasi tersebut terwujud dalam bentuk kesediaan menyediakan berbagai macam perlengkapan sarana dan prasarana yang dibutuhkan dalam proses pengabdian, seperti gedung, mempersiapkan sound system, dan LCD. Pada pelaksanaan acara di buka oleh MC dan selanjutnya ucapan selamat datang dan sambutan dari lurah Bolihuangga, Kecamatan Limboto, Kabupaten Gorontalo. Penyampaian materi oleh tim pengabdian dari dosen jurusan Epidemiologi dan Kesehatan Reproduksi, Fakultas Kesehatan Masyarakat Universitas Gorontalo.

Kegiatan pengabdian kepada masyarakat yang dilaksanakan dengan cara tatap muka berjalan dengan baik dan lancer dengan tetap mentaati protokol kesehatan mengingat pelaksanaan pada masa pandemic Covid 19. Pertemuan tatap muka menggunakan metode ceramah, penayangan film pendek tentang akibat pernikahan dini dan tanya jawab yang melibatkan seluruh peserta remaja putra dan putri berjumlah 32 peserta. Pada sesi tanya jawab yang secara antusias diajukan oleh peserta, tampak bahwa peserta masih belum paham tentang program pendewasaan usia perkawinan (PUP) dan dampak negatif pernikahan dini dari berbagai aspek.

\section{Penyuluhan Kesehatan sebagai Upaya Pencegahan Pernikahan Usia Dini dan Pembagian Leaflet}

Penyuluhan dan pembagian leaflet ini dilakukan untuk menunjang peningkatan pengetahuan, sikap, dan kesadaran diri remaja tentang konsep pendewasaan usia perkawinan, hak-hak reproduksi remaja, pendewasaan usia kawin remaja, program pendewasaan usia kawin remaja, dampak negatif pernikahan usia dini sehingga diharapkan remaja putra dan putri memiliki kemampuan untuk melakukan kontrol diri terkait kesehatan reproduksinya dan sebagai pemberi edukasi bagi teman sebaya nantinya.

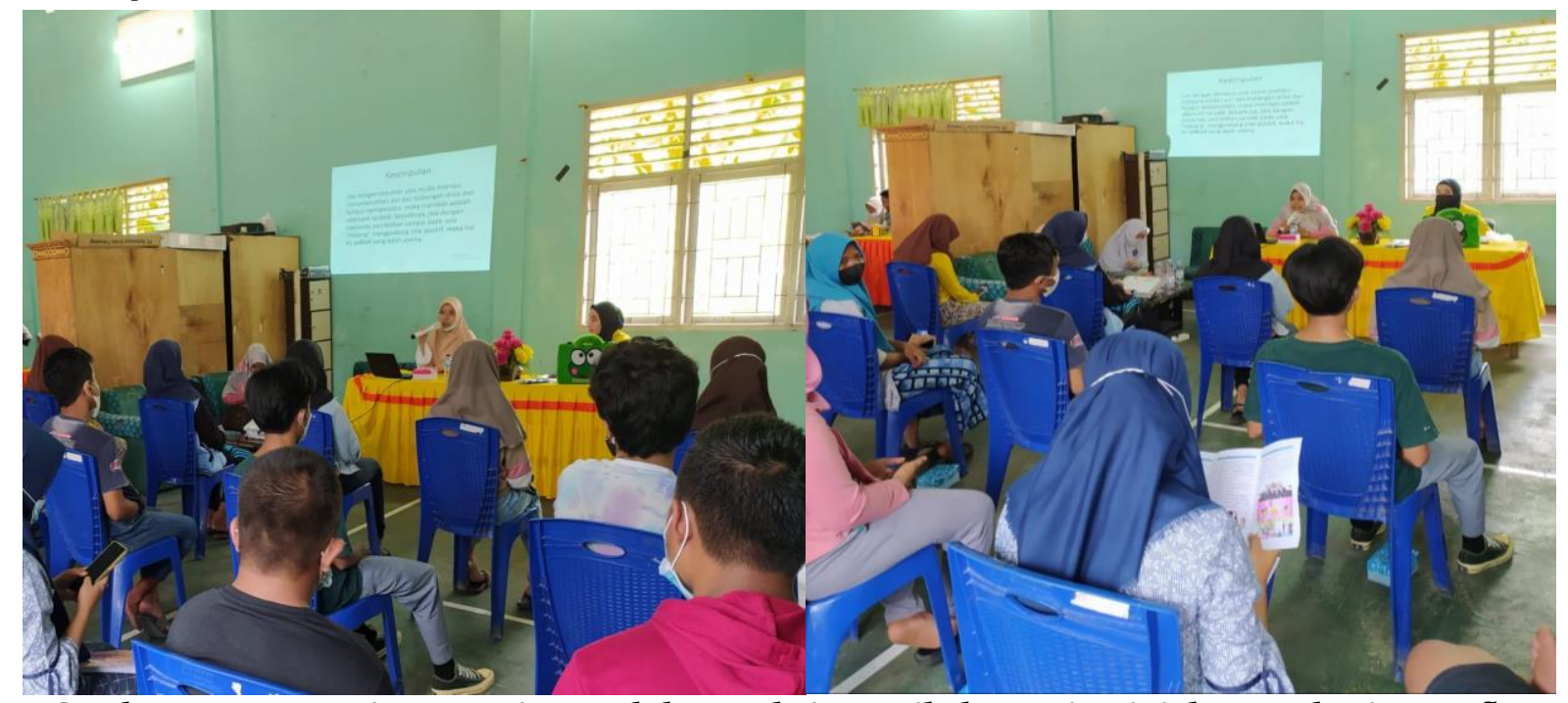

Gambar 1. Penyampaian Materi Penyuluhan terkait Pernikahan Usia Dini dan Pembagian Leaflet 


\section{Penayangan Film Pendek tentang Dampak Negatif Pernikahan Dini dan Diskusi}

Penayangan film pendek ini sebagai penunjang dan media literasi dalam memahami seluk beluk pernikahan usia dini dan dampaknya sehingga dengan hal tersebut dapat meningkatkan kesadaran remaja untuk tidak melakukan pernikahan di usia dini. Setelah pemutaran film pendek, para peserta dimimta untuk menyimpulkan nilai moral yang diperoleh selama dari film tersebut. Salah satu remaja yang merupakan peserta memberi tanggapan bahwa dari film tersebut dapat dilihat pasangan yang menikah muda kemudian hamil, namun secara psikis maupun secra ekonomi belum siap dan pada akhirnya hanya penyesalan yang dirasakan oleh pasangan tersbut. Setelah itu, para peserta diminta untuk membuat komitmen diri atau ajakan agar tidak menikah dini. Dengan harapan setelah membuat komitmen tersebut, peserta dapat menanamkan komitmen pada dirinya untuk menikah sesuai dengan umur idealnya.

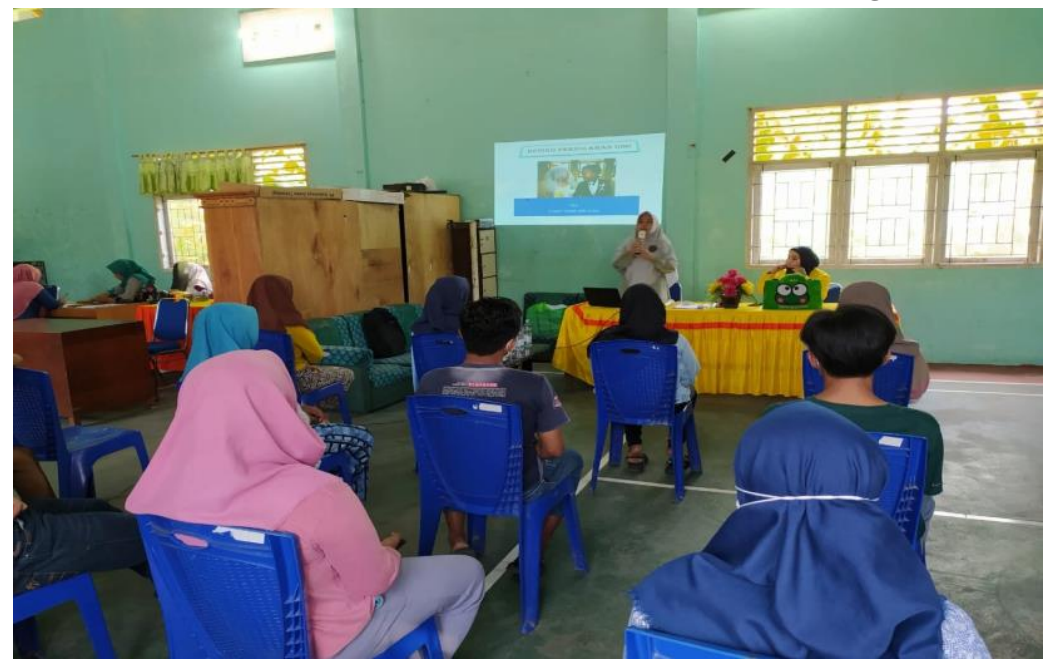

Gambar 2. Penayangan Film Pendek tentang Dampak Negatif Pernikahan Usia Dini dan Diskusi

\section{Pembentukan Komunitas Fresh Milk (Forum Remaja Sehat Milenial dan Kreatif)}

Pembentukan komunitas ini bertujuan untuk menunjang keberlanjutan program komunikasi intens antara pihak kampus dan peserta penyuluhan sehingga nantinya anggota dapat menjadi penerus yang akan menjadi pengerak terkait pencegahan pernikahan usia dini. Melalui komunitas ini juga nantinya bisa dirumuskan kegiatankegiatan untuk mendukung terwujudnya remaja anti pernikahan dini.

Adapun yang menjadi anggota komunitas ini yaitu remaja putra putri usia sekolah (16- 18 tahun) yang secara rutin akan didampingi untuk melakukan diskusi dan motivasi terhadap sesama remaja lain di luar komunitas. Dalam komunitas ini akan dilakukan pendampingan serta pemberdayaan agar nilai-nilai mengenai kesadaran diri tentang risiko atau dampak negatif pernikahan dini dapat tertanam dan kemudian diaplikasikan dalam kehidupan sehari-hari. Komunitas ini dilengkapai dengan grup komunikasi melalui sosial media yaitu WhatsApp untuk membantu kelancaran komunikasi antara satu sama lain. 


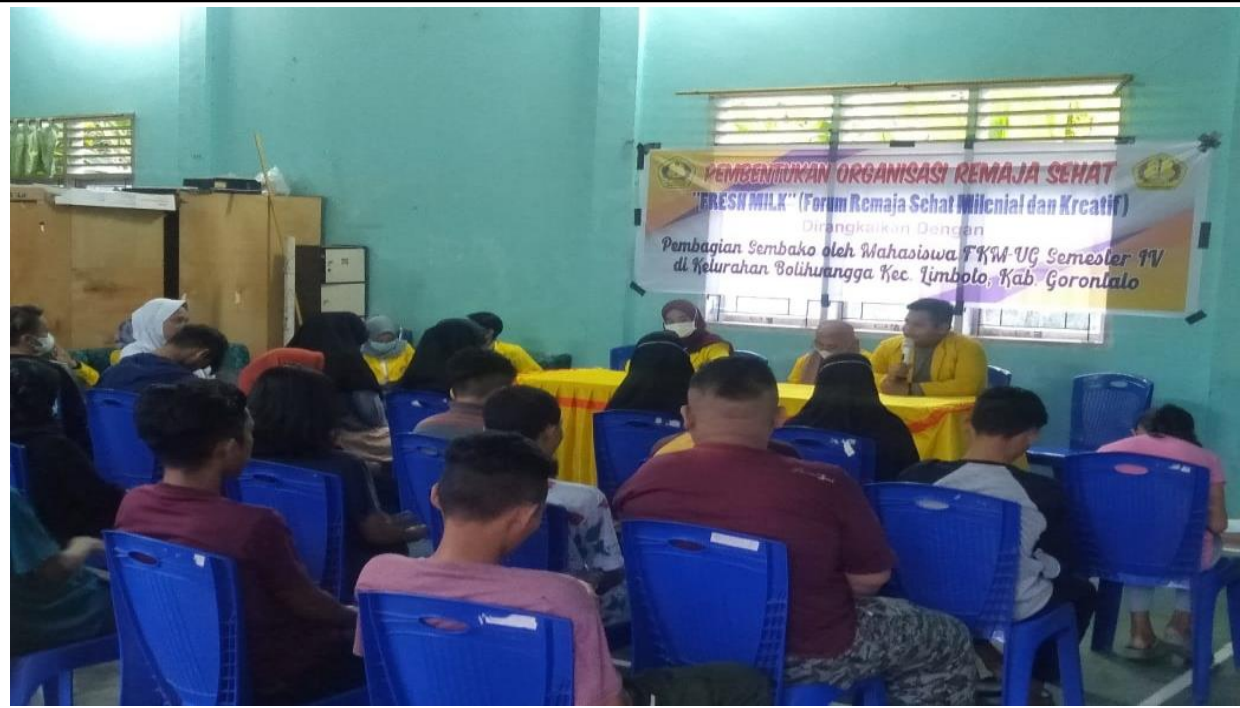

Gambar 3. Pembentukan Komunitas Fresh Milk "Forum Remaja Sehat Milenial dan Kreatif"

Ketercapaian tujuan pelaksanaan kegiatan pengabdian masyarakat secara umum sudah baik, dilihat dari pengamatan langsung saat penyampaian materi peserta tampak antusias memperhatikan dan bertanya. Dalam acara tanya jawab peserta dapat menjelaskan kembali dengan kata-katanya sendiri tentang materi yang disampaikan. Maka dapat disimpulkan bahwa tujuan kegiatan ini dapat tercapai.

Ketercapaian target materi pada kegiatan pengabdian pada masyarakat ini cukup baik, karena materi telah disampaikan secara keseluruhan. Materi yang telah disampaikan meliputi konsep pendewasaan usia perkawinan, hak-hak reproduksi remaja, program pendewasaan usia kawin remaja, dan dampak negatif pernikahan usia dini. Keberhasilan kegiatan ini juga dapat dilihat dari kepuasan peserta setelah mengikuti kegiatan. Manfaat yang diperoleh remaja putra dan putri adalah dapat menjadi tambahan pengetahuan tentang konsep pendewasaan usia perkawinan, hakhak reproduksi remaja, pendewasaan usia kawin remaja, program pendewasaan usia kawin remaja, dampak negative pernikahan usia dini sehingga diharapkan remaja putri memiliki kemampuan untuk melakukan kontrol diri dan lebih memperhatikan kesehatan reproduksinya. Remaja yang awalnya kurang memahami berkaitan dengan dampak negatif dari perkawinan usia dini menjadi semakin mengerti dan memahami bahaya atau dampak dari perkawinan usia dini.

Program sosialisasi ini juga dilakukan proses monitoring. Monitoring program dilakukan sejak awal dimulainya kegiatan ini dari tahap persiapan, proses pelaksanaan, sampai tahap akhir kegiatan. Setiap akhir tahapan kegiatan dilakukan monitoring guna mengetahui apakah pelaksanaan program sesuai dengan rencana program yang telah dibuat. Berdasarkan evaluasi dan masukan dari para peserta, banyak kemanfaatan yang diperoleh melalui program ini. Remaja putra dan putri mengatakan menjadi lebih paham tentang hak-hak reproduksi, dampak negatif dan bahaya perkawinan usia dini. 


\section{KESIMPULAN}

Pelaksanaan pengabdian pada masyarakat berupa Pencegahan Pernikahan Usia Dini Melalui Penyuluhan Kesehatan di Kelurahan Bolihuangga dapat diselenggarakan dengan baik dan berjalan lancar sesuai dengan rencana kegiatan yang telah disusun. Secara umum remaja putra dan putri dapat menjelaskan tentang konsep pendewasaan usia perkawinan, hak-hak reproduksi remaja, program pendewasaan usia kawin remaja, dan dampak negatif pernikahan usia dini, meskipun belum semua peserta menguasai dengan baik materi yang disampaikan. Kegiatan ini mendapat sambutan yang baik terbukti dengan keaktifan peserta saat mengikuti kegiatan tersebut.

Berdasarkan evaluasi yang telah dilakukan perlu adanya kegiatan lanjutan sejenis yang dilakukan secara periodik sehingga dapat lebih meningkatkan pengetahuan dan kesadaran diri remaja serta perlu penambahan sasaran yaitu orang tua dari remaja, karena orang tua memegang peranan penting dalam proses pendidikan di rumah tangga sehingga perlu wawasan yang luas agar dapat membimbing dan bekerjasama dengan anak remajanya terkait dengan hak-hak reproduksi dan pendewasaan usia perkawinan. Selain itu, perlu adanya pembinaan agar meningkatkan pemahaman keluarga untuk mencegah pernikahan dini. Pembinaan dalam program ini berupa kegiatan konsultasi berkala secara rutin. Serta perluasan wilayah pengabdian ke tingkat Kecamatan Limboto dengan memperbanyak pula alat peraga berupa modul untuk selanjutnya dapat diberikan dan disosialisasikan pada tingkat kecamatan dengan bekerjasama dengan Komunitas Remaja Sehat Milenial dan Kreatif.

\section{REFERENSI}

Badan Pusat Statistik. (2020). Pencegahan Perkawinan Anak percepatan yang tidak bisa ditunda. Badan Pusat Statistik, pp. o-44.

Fitra, Hardi. (2017). Pengaruh Perkawinan di Bawah Umur terhadap Tingkat Perceraian di Kabupaten Aceh Tengah, diakses dari https://repository.arraniry.ac.id/3180/1/hardi\%2ofitra.pdf pada 20 April 2021.

Kementrian Agama Kabupaten Gorontalo. (2020). Data Peristiwa Nikah di Bawah Umur Limbong, M., Deliviana, E. and Indonesia, U. K. (2020). Jurnal Comunita Servizio A bstrak Jurnal Comunita Servizio', 2, pp. 321-329.

Suciati, Sofyan. (2019). Pemberdayaan Pasangan Usia Dini Melalui Komunikasi Keluarga "Samawa" dan Gerakan Anti Perceraian (GAP). PKM, UMY Yogyakarta.

UNICEF. (2014). Ending Child Marriage Progress and prospects. https://lifestyle.kompas.com/read/2018/o9/05/o95311620/ini-akibat-yang-terjadi-daripernikahan-dini. 